\title{
Paget's Disease of the Nipple Presenting as Non-Healing Ulcerative Lesion of Nipple: A Case Report and Review of Literature
}

\author{
JB Singh*1, Mabruka Jeelani ${ }^{2}$, Afiya Shafi ${ }^{3}$ and Nadia Jeelani ${ }^{4}$ \\ ${ }^{1}$ Associate professor, India \\ ${ }^{2}$ Tutor Demonstrator, India \\ ${ }^{3}$ Associate professor, India \\ ${ }^{4}$ Tutor Demonstrator, India
}

*Corresponding author: JB Singh, Associate professor, pathology, India

\section{ARTICLE INFO}

Received: 豐 February 05, 2019

Published: 幽 February 14, 2019

Citation: JB Singh, Mabruka Jeelani, Afiya Shafi, Nadia Jeelani. Paget's Disease of the Nipple Presenting as Non-Healing Ulcerative Lesion of Nipple: A Case Report and Review of Literature. Biomed J Sci \& Tech Res 14(4)-2019. BJSTR. MS.ID.002577.

\section{ABSTRACT}

Paget's disease of the breast is a rare condition of the nipple areola complex and is often associated with an underlying in situ or invasive carcinoma. It continues to pose as a diagnostic dilemma.

Keywords: Breast Carcinoma; Breast; Nipple; Paget's Disease Of Breast; Eczema; Biopsy

\section{Introduction}

Pagets disease of the nipple is a form of ductal carcinoma in situ. It involves subareolar ducts and skin of the nipple and areola. However, tumor may invade the adjutant tissue and cause invasive disease. Characteristically the nipple is ulcerated, eczematoid and may be destroyed. The eczematous presentation is the most misleading feature of this disease. Such patients are usually treated by the physician mistakenly for eczema. Hence, it is difficult to develop a standard algorithm for the management of this disease. A case of Paget's disease of nipple is presented along with a review of literature.

\section{Case Report}

We report a case of Paget's disease of the breast in a 45-year-old woman who presented with a long standing non-healing ulcerative lesion of the left nipple-areola complex. She gave the history of itching over the lesion. The lesion increased in size over the next period of months. There was no family history of cancer and no history of any nipple discharge. Physical examination did not reveal any palpable mass in any quadrant quadrant of both breasts or in the axilla. Full thickness skin biopsy done from the left nipple revealed the histopathological diagnosis of Paget's disease of the nipple. Margins could not be identified upon due to the small nature of the biopsy. Complete clinical workup was advised including radio imaging to rule out underlying duct cell carcinoma. Mammography reported a lesion of BIRADS grade III . Ultrasonography showed a suspected glactophoric dilatation of the left super-external quadrant. The patient was scheduled for a left modified radical mastectomy and sentinel lymph node biopsy (Figure 1). The final histopathological diagnosis was Paget's disease of the left breast with ductal carcinoma in situ with comedy pattern. There was no metastasis noted in the lymph nodes received. Receptor studies done showed absence of estrogen and progesterone receptors, however, Her2 Neu was positive along with CK-7. 


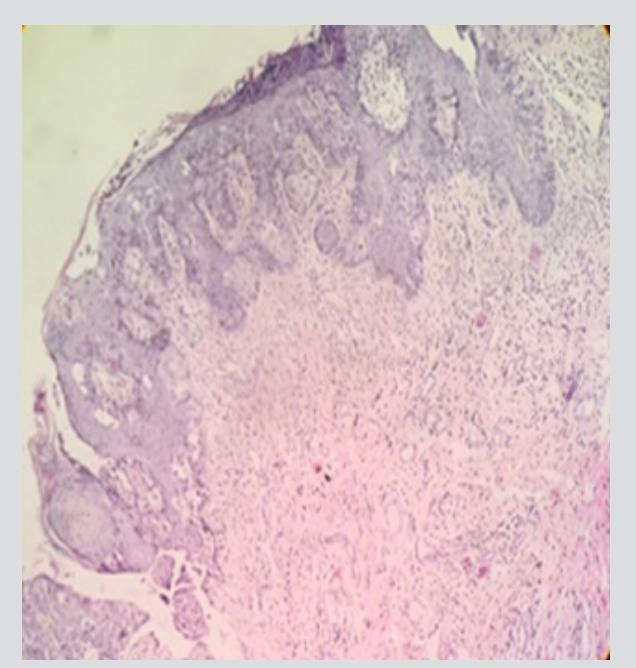

Figure 1: Pagets Disease $10 \mathrm{X}$.

\section{Discussion}

In 1874, Sir James Paget described "an eruption on the nipple and areola" with characteristics of "ordinary chronic eczema" [1] Paget's disease of breast must be considered with the presence of a persistent eczematous involvement of nipple, which does not respond to treatment. Radiographic imaging can further guide in searching an underlying lesion. The prognosis depends on the presence of a palpable mass and invasiveness of the carcinoma [2]. Velpeau first described the eczematous lesions of the Pagets disease of the nipple in 1856 but it was Sir James Paget who first described the association of Paget's disease of the breast with underlying breast cancer in 1874 and accordingly this condition was named after him [3]. Pagets disease of the breast is an uncommon presentation of breast with a reported incidence of 3\% [4-6]. It is accompanied by in a nearly all instances by a underlying breast carcinoma in situ, ductal type, with or without associated stromal invasion. the management and Prognosis depend largely on the intra ductal versus invasive nature of the underlying carcinoma and on the presence or absence of axillary lymph node involvement $[7,8]$.

Pagets disease of breast is pathologically characterized by the infiltration of the nipple epidermis by large, clear, ballooned cells, now recognized as malignant breast epithelial cells, which cause an eczematous eruption on the nipple and areola $[9,10]$. Though it is more frequently found in females, it is even seen in males in whom it has a very poor prognosis [6] Clinically, these weeping, eczema like lesions are centered in the nipple. Later they may involve the areola and surrounding dermis, but they rarely extend more than a few centimeters. If a definite mass can be palpated benath the diseased nipple, the underlying tumor, will have an invasive component in over $90 \%$ of cases. Conversely, $66 \%$ without a palpable mass are exclusively intraductal [11]. Conditions closely simulating Paget's disease of the nipple include eczema, erosive adenomatosis of nipple, pagetoid basal cell carcinoma, Bowen's disease and melanoma. Hence full thickness tissue biopsy is essential to arrive at a pathological diagnosis (Figure 2). Histologically, Paget's disease is characterized by epidermal invasion by malignant glandular cells, which are large, foamy, that may contain mucin $[8,12]$. The cells can be isolated or in clusters and sometimes form small glandular structures [13]. In rare instances they have an anaplastic appearance [14] histological diagnosis should be followed by a complete evaluation of the breast for presence of multicentricity [8].

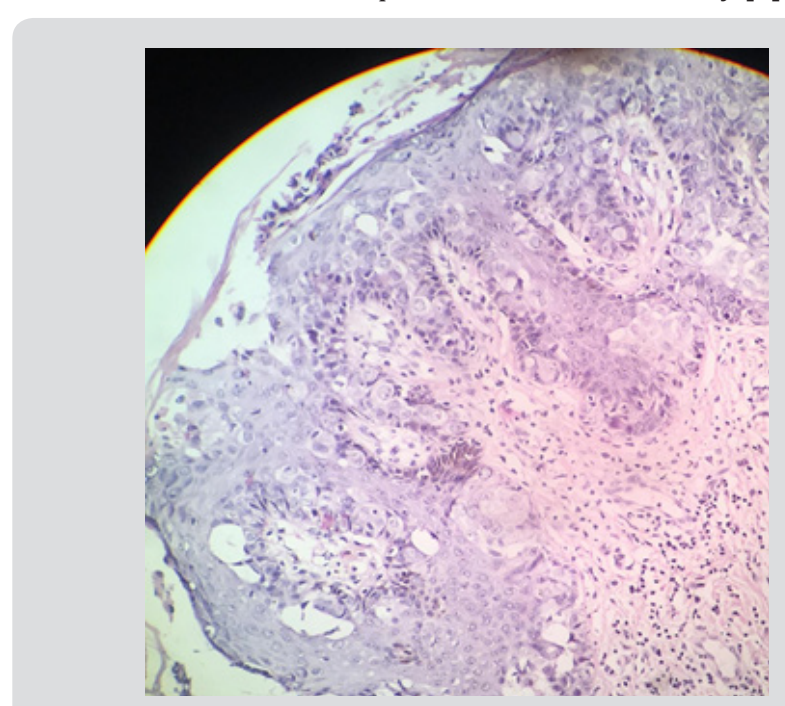

Figure 2: The microphotograph depicts cells which are large hyperchromatic and anaplastic, surrounded by clear area, the clear area contains mucopolysaccharides (paget cells).

Surgical option is the best way to manage, any adjuvant therapy is decided on evaluation of case, for localized DCIS, breast conserving surgery, irradiation, following surgery is considered. Chemotherapy in management of DCIS is not substantiated, hormonal therapy should be considered even in case of DCIS. In case lymph node invasion is seen, adjuvant systemic therapy along with irradiation is indicated. Invasive form of Paget's associated with lump and lymph node involvement is treated on same guidelines as classical breast carcinoma.

\section{Conclusion}

A unilateral eczematous nipple lesion needs to be evaluated promptly by way of a breast biopsy. Paget's disease of the breast accompanied with an invasive tumor with or without lymph node involvement decides the best surgical option and the need for adjuvant therapy.

\section{References}

1. Paul peter Rosen, syed A Hoda. Rosen's breast pathology, Fourth edition, p. 30-775.

2. Durbar S, Boukrid M, Bouquet de Joliniere J, Guillou L, Vo QD, et al. (2017) Paget's Breast Disease: A Case Report and Review of the Literature. Front Surg 4: 51.

3. Osther PJ, Balslev E (1990) Paget's disease of the nipple. A continuing enigma. Acta Chir Scand 156(5): 343-352.

4. Dalberg K, Hellborg H, Warnberg F (2008) Paget's disease of the nipple in a population-based Cohort. Breast Cancer Res Treat 111(2): 313-319.

5. Saorafas GH, BlanchordDK, Sarr MG, Farley DR (2001) Pagets disease of the breast. Cancer Treat 27(1): 9-18. 
6. Sakorafas GH, Blanchard DK, Sarr MG (2001) Pagets disease of the breast : a clinical perspective. Lange backs disease of the breast 386(6) 444-450.

7. Juan Rosai, Rosai. Ackermans's Surgical Pathology, Tenth Edition 2: 20 1706

8. Panone JF, Baker RR (1981) Pathogenesis and treatment of Pagets disease of the breast. Cancer 48(3): 825-829.

9. Velpeau S (1856) Treatise on diseases of the breast and mammary region. Sydenham Society, London.

10. Hong Ling, Xin Hu, Xu XL, Liu ZB, Shao ZM (2013) Patients with nipple-areola Pagets disease and underlying invasive breast carcinoma have very poor survival : A matched Cohort study. PLos One 8(4): 61455.

\section{ISSN: 2574-1241}

DOI: 10.26717.BJSTR.2019.14.002577

JB Singh. Biomed J Sci \& Tech Res

(C) This work is licensed under Creative

Submission Link: https://biomedres.us/submit-manuscript.php
11. Ashikari R, Park K, Huvous AG, Urban JA (1970) Pagets disease of the breast. Cancer 26: 680-685.

12. Lev Schelouch D, Sperber F, Gat A, Klausner J,Gutman M (1981) Pagets disease of the breast. Cancer 48(3): 825-829.

13. Shousha S (2007) Glandular Pagets disease of the nipple. Histopathology $50(6)$ : 812-814.

14. Rayne SC, Santa Cruz DJ (1992) Anaplastic Pagets Disease. Am J Surg Pathol 16(11): 1085-1091.

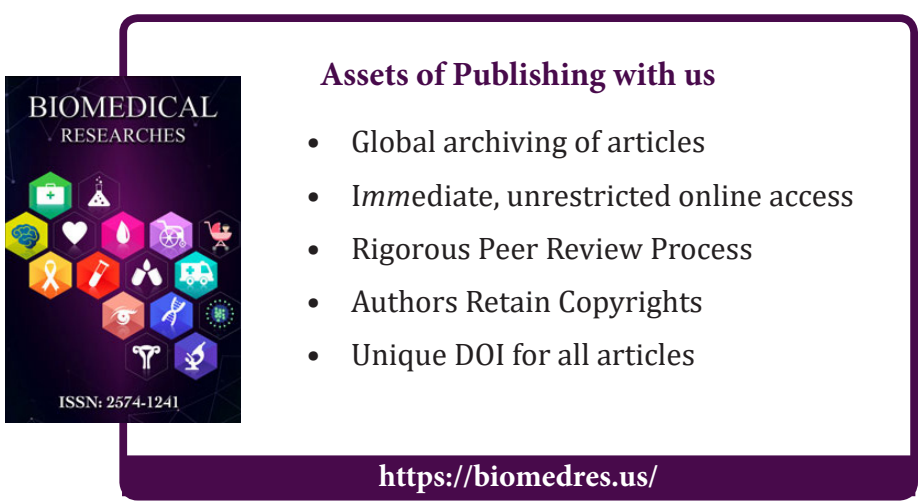

